\title{
DETERMINASI RELIGIUSITAS, KECERDASAN EMOSIONAL, DAN DUKUNGAN SOSIAL TERHADAP KECEMASAN AKADEMIK SISWA
}

\author{
Ely Roy Madoni' ${ }^{1}$, Abidatul Mardliyah ${ }^{2}$ \\ ${ }^{1}$ Dosen Fakultas Keguruan dan Ilmu Pendidikan, Universitas Darul 'Ulum, Indonesia \\ ${ }^{2}$ Dosen Fakultas Tarbiyah, Institut Agama Islam Bani Fattah Jombang, Indonesia \\ E-mail: roy.bk@undar.ac.id, abidatulmardliyah@iaibafa.ac.id
}

\begin{abstract}
ABSTRAK
Kecemasan merupakan perasaan campur aduk yang berisi perasaan ketakutan dan prihatin tanpa diketahui penyebabnya terhadap pengalaman atau peristiwa yang belum terjadi. Kecemasan terbesar sering terjadi pada saat siswa menghadapi tuntutan dan tugas akademik. Penelitian ini fokus menjawab permasalahan tentang apakah terdapat korelasi antera religiusitas, kecerdasan emosional dan dukungan sosial dengan kecemasan akademik siswa. Subyek penelitian adalah siswa SMK Negeri $X$ Jombang yang diambil secara proportional stratified. Data penelitian dikumpulkan dengan menggunakan empat instrumen yakni skala religiusitas, skala kecerdasan emosi, skala dukungan sosial dan skala kecemasan. Analisis data penelitian yang digunakan adalah multiple regression dan partial correlation. Hasil penelitian membuktikan bahwa religiusitas, kecerdasan emosional, dan dukungan sosial memberikan sumbangan 10,7\% terhadap kecemasan akademik siswa. Dengan demikian 89,3\% kecemasan dipengaruhi oleh variabel-variabel lain. Siswa diharapkan mampu menerapkan religiusitas dalam kehidupan sehari-hari dan mengetahui serta mengarahkan segenap kekurangan dan kelebihan dalam dirinya. Sekaligus memlikiki kemampuan menjalin relasi sosial yang positif dengan lingkungan di sekitarnya.
\end{abstract}

Kata Kunci: religiusitas;kecerdasal-emosional; dukungan-sosial; kecemasan-akademik

\begin{abstract}
Anxiety is a mixed feeling that contains feelings of fear and concern with no known cause for experiences or events that have not yet occurred. The greatest anxiety often occurs when students face academic demands and assignments. The research focuses on answering the problem of whether there is a correlation between religiosity, emotional-intelligence and social-support with students' academic anxiety. The research subjects were students of SMK Negeri X Jombang who were taken in a proportional stratified manner. The research data were collected using four instruments, namely the religiosity scale, emotional intelligence scale, social support scale and anxiety scale. The analysis of the research data used was multiple regression and partial correlation. The results of the study proved that religiosity, emotional intelligence, and social support contributed $10.7 \%$ to students' academic anxiety. Thus $89.3 \%$ of anxiety is influenced by other variables. Students are expected to be able to increase religiosity in everyday life and to know and direct all the weaknesses and strengths in themselves. As well as having the ability to establish positive social relationships with the environment around them.
\end{abstract}

Keywords: religiosity; emotional-intelligence; social-support; academic-anxiety 


\section{PENDAHULUAN}

Kecemasan merupakan aspek pembentuk motivasi instrinsik bagi individu jika dalam intensitas normal. Selain itu, kecemasan juga menjadi komponen penting yang mempengaruhi dinamika pendidikan, pembelajaran, perhatian, konsentrasi dan performa akademik (Schunk dkk, 2014). Kecemasan yang normal mampu membangkitkan motivasi siswa untuk memiliki kemampuan melaksanakan tugas atau pekerjaan dengan lebih baik dan tepat waktu. Namun demikian, kecemasan dengan intensitas yang tinggi akan memberikan dampak buruk bagi perkembangan akademik siswa (Madoni dkk, 2018).

Kecemasan dikenal sebagai suatu kondisi emosional yang negatif dengan indikasi adanya rangsangan fisiologis, rasa tegang yang mengganggu, serta perasaan terganggu bahwa hal yang tidak baik akan terjadi (Nevid dkk, 2005). Kecemasan akademik merupakan tekanan, ketakutan, atau stres yang dirasakan oleh siswa sebagai akibat dari tuntutan sekolah yang harus dilaksanakan (O'Connor, 2008). Proses belajar mengajar maupun kegiatan belajar lainnya menjadi sumber tekanan akademik siswa. Tes/ujian, kompetisi nilai, tuntutan waktu, guru, lingkungan kelas/sekolah, karier dan masa depan sering menjadi tekanan akadamik yang dialami siswa (Ifdil \& Bariyyah, 2015). Beberapa hasil penelitian menunjukkan pengaruh yang negatif tingkat kecemasan dengan kinerja akademik siswa. Penelitian yang lain juga memberikan bukti bahwa tingkat kecemasan yang tinggi pada siswa menunjukkan capaian akademik yang lebih rendah pula daripada siswa yang memiliki tingkat kecemasan rendah (Puteh \& Z., 2016; Wahid dkk, 2018).

Dengan adanya berbagai dampakdampak negatif tersebut, maka perlu adanya upaya preventif untuk mencegah tingginya tingkat kecemasan akademik siswa dengan mengetahui faktor-faktor determinan yang mempe-ngaruhi. Salah satu faktor yang menentukan kecemasan akademik adalah religiusitas atau beberagamaan. Penelitian terdahulu membuktikan adanya pengaruh negatif tingkat religiusitas dengan tingkat kecemasan akademik yang signifikan pada peserta didik di Madrasah Aliyah Negeri Kota Palembang. Peserta didik dengan tingkat religiusitas yang tinggi, lebih cenderung memiliki tingkat kecemasan akademik yang rendah, begitu juga sebaliknya (Ukhtia dkk, 2016).

Pengalaman spiritual mampu meningkatkan level kesejahteraan seseorang sehingga terhindar dari tekanan, rasa cemas dan depresi. Seseorang yang memiliki predikat tinggi pada aspek religiusitas dipastikan memiliki daya tahan yang lebih baik. Agama mampu membuat psikis siswa yang mengalami kebimbangan menjadi lebih mantap kembali (Hawari, 1997).

Selain religiusitas, kemampuan manajemen emosi diri yang erat sekali hubungannya dengan kecerdasan emosi, menjadi faktor lain yang mempengaruhi kecemasan akademik siswa. Kecerdasan emosi merupakan aspek emosional yang penting bagi siswa untuk memahami dan mengendalikan emosi-emosi diri, serta membangun relasi yang baik dengan orang lain. Kecerdasan emosi siswa mempengaruhi siswa dalam mengambil keputusan yang berkaitan dengan masalah-masalah diri dan sosial yang berhubungan dengan emosi (Farid, 2011).

Peserta didik dengan tingkat kecerdasan emosi yang tinggi tinggi cenderung lebih peduli, berempati, simpati terhadap penderitaan, memiliki kemampuan dalam membedakan suasana hati dan 
memberiknya respon yang tepat, perilaku yang tempramen, memiliki motivasi dan hasrat sosial. Kondisi tersebut sesuai dengan pendapat Goleman (2002) yang berkaitan dengan aspek kecerdasan emosi tentang mengelola dan memotivasi diri, mampu mengatasi kecemasan, perasan murung, perasaan tersinggung, mampu bangkit dari keterpurukan, positive thinking, tidak mudah putus asa dan kehilangan harapan. Penelitian membuktikan bahwa kecerdasan emosi memiliki peranan yang penting sekali dalam melepaskan dan bahkan menghindari kecemasan dalam perencanaan masa depan (Nuraini, 2013).

Selain religiusitas dan kecerdasan emosional, dukungan sosial juga menjadi faktor lain yang berpengaruh terhadap kecemasan siswa. Siswa yang termasuk dalam masa remaja akan lebih banyak mendapatkan dukungan sosial, terutama dukungan dari keluarga, guru dan temanteman sebayanya. Buhrmester (Papalia dkk, 2007) mengemukakan bahwa kelompok teman sebaya merupakan wadah untuk mengeksplorasi perasaan, rasa simpati, pemahaman pedoman moral, wadah untuk bereksperimen, dan tempat untuk memperoleh otonomi. Pada tahap perkembangan remaja, teman sebaya menjadi faktor yang sangat penting pengaruhnya secara emosional maupun secara sosial. Selain itu, intensitas keterlibatan remaja dengan teman sebayanya juga akan menjadi sumber tekanan bagi meraka.

\section{METODE}

Penelitian ini menggunakan pendekatan korelasional yang berupaya untuk menemukan korelasi antara satu variabel dengan variabel lain yang bertujuan menemukan konstruk/bentuk dan wujud yang berbeda dari sebelumnya (Sugiono, 2014). Penelitian ini dilaksanakan untuk membuktikan adanya determinasi religiusitas, kecerdasan emosional, dan dukungan sosial terhadap kecemasan akademik siswa.

Subyek dalam penelitian ini merupakan peserta didik yang masuk pada tingkatan kelas XII di SMK Negeri X Jombang yang diambil dengan secara proportional stratified sampling. Pengambilan sampel sangat memperhatikan pertimbangan antara banyaknya jumlah anggota populasi yang ada pada setiap strata, sehingga memungkinkan sampel yang diambil benarbenar menjadi sampel yang terbaik.

Instrumen/skala yang digunakan terdiri dari: skala kecemasan yang dikembangkan dari teori Krol (Asnani, 2004) diperoleh koefisien realibilitas sebesat 0.715 , skala religiusitas yang dikembangkan oleh Koenig (Koenig dkk, 2004) diperoleh koefisien realibilitas sebesar 0.729 , skala kecerdasan emosional yang dikembangkan oleh Mayer (Mayer dkk, 2004) diperoleh koefisien realibilitas sebesat 0.718 , dan skala dukungan sosial yang diadaptasi dari Cohen (Cohen \& Wills, 1995) diperoleh koefisien realibilitas sebesat 0.731 . Hasil analisis ini menunjukkan bahwa koefisien realibilitas skala kecemasan akademik, religiusitas, kecerdasan emosional, dan dukungan sosial telah melebihi batas minimum koefisien realibilitas 0.700 , sehingga dinyatakan reliabel.

Untuk menguji determinasi religiusitas, kecerdasan emosional dan dukungan sosial dengan kecemasan akademik, data penelitian akan dianalisis menggunakan analisis multiple regression. Untuk menguji korelasi setiap variabel independen, yakni religiusitas, kecerdasan 
emosional dan dukungan sosial, akan digunakan analisis korelasi secara parsial.

HASIL DAN PEMBAHASAN
Pengujian hipotesis dengan analisis multiple regression mendapatkan hasil $\mathrm{R}=$ 0,$107 ; F=3,209 ; p=0,027(p<0,05)$ dati tabel koefisien determinasi berikut.

Tabel 1. Koefisien Determinasi

Model Summary

\begin{tabular}{|c|c|c|c|c|c|c|}
\hline \multirow[b]{2}{*}{ Model } & \multicolumn{5}{|c|}{ Change Statistics } & \multirow[b]{2}{*}{ Durbin-Watsor } \\
\hline & $\begin{array}{c}\text { R Square } \\
\text { Change }\end{array}$ & F Change & $\mathrm{df1}$ & $\mathrm{df} 2$ & Sig. F Change & \\
\hline 1 & $107^{a}$ & 3,209 & 3 & 80 & ,027 & 1,943 \\
\hline
\end{tabular}

a. Predictors: (Constant), Religiusitas, Kecerdasan Emosional, Dukungan Sosial

b. Dependent Variable: Kecemasan Akademik

Data penelitian menunjukkan R2 = 0,107 yang berarti $10,7 \%$ proporsi variasi kecemasan akademik dijelaskan secara bersama-sama oleh variabel religiusitas, kecerdasan emosional, dan dukungan sosial. Hasil analisis memperlihatkan bahwa secara simultan variabel religiusitas, kecerdasan emosional dan dukungan sosial memiliki korelasi dengan kecemasan akademik. Analisis tersebut menggambarkan bahwa, apabila tingkat religiusitas, kecerdasan emosional dan dukungan sosial tinggi, maka tingkat kecemasan akademik siswa akan semakin rendah dan juga sebaliknya. Yang berarti bahwa religiusitas, kecerdasan emosional dan dukungan sosial dapat dijadikan sebagai dasar untuk memprediksi kecemasan akademik siswa. Selanjutnya data uji t parsial dapat dilihat pada tabel di bawah ini.

\section{Tabel 2. Data Uji t Parsial}

\section{Coefficients ${ }^{a}$}

\begin{tabular}{lccccc}
\hline \multirow{2}{*}{ Model } & \multicolumn{2}{c}{$\begin{array}{c}\text { Unstandardized } \\
\text { Coefficients }\end{array}$} & $\begin{array}{c}\text { Standardized } \\
\text { Coefficients }\end{array}$ & $\mathrm{t}$ & Sig. \\
\cline { 2 - 5 } & $\mathrm{B}$ & Std. Error & Beta & & \\
\hline 1. (Constant) & 63,252 & 10,648 & & 5,940 &, 000 \\
Religiusitas &,- 322 &, 124 &,- 069 &,- 563 &, 025 \\
Kecerdasan Emosional &,- 442 &, 138 &,- 063 &,- 503 &, 016 \\
Dukungan Sosial &,- 313 &, 083 &,- 257 & $-2,122$ &, 037 \\
\hline
\end{tabular}

Berdasar pada hasil analisis data sebesar $\mathrm{t}=-0,313$ dengan sig $(\mathrm{p})=0,025$ dengan uji $t$, diperoleh hasil untuk atau $p<0,05$, menunjukkan bahwa secara religiusitas dengan kecemasan akademik signifikan ditemukan adanya korelasi yang 
negatif tingkat religiusitas siswa dengan tingkat kecemasan akademik siswa. Sehingga dapat ditarik kesimpulan bahwa siswa dengan derajat religiusitas yang semakin tinggi, kecemasan akademiknya akan semakin menurun. Selanjutnya hasil analisis data uji $t$ untuk kecerdasan emosional dengan kecemasan akademik sebesar $t=-0,442$ dengan sig $(p)=0,016$; atau $p<0,05$, menunjukkan bahwa kecerdasan emosional memiliki korelasi negatif yang signifikan terhadap kecemasan akademik siswa. Sehingga dapat ditarik kesimpulan bahwa siswa dengan derajat kecerdasan emosional yang lebih tinggi mampu menunjukkan tingkat kecemasan akadmik yang lebih rendah rendah. Berikutnya hasil analisis data uji $\mathrm{t}$ untuk dukungan sosial dengan kecemasan akademik sebesar $\mathrm{t}=-0,313$ dengan sig $(\mathrm{p})$ $=0,037$ atau $p<0,05)$, menunjukkan bahwa secara signifikan terdapat adanya korelasi yang negatif variabel dukungan sosial dengan variabel kecemasan akademik siswa. Dapat dijelaskan bahwa siswa dengan tingkat dukungan sosial yang semakin tinggi, akan memiliki kecemasan akademik yang semakin rendah.

Penafsiran di atas menunjukkan bahwa, secara parsial kecemasan akademik dipengaruhi oleh religiusitas sebesar 3,2\%, kecerdasan emosional sebesar 4,4\%, dukungan sosial sebesar $3,1 \%$, dan selebihnya $89,3 \%$ dipengaruhi oleh faktorfaktor yang lainmya. Dengan demikian hipotesis yang menyatakan adanya determinasi religiusitas, kecerdasan emosional dan dukungan sosial dengan kecemasan akademik, teruji.

Hasil penelitian menunjukkan adanya determinasi religiusitas, kecerdasan emosi dan dukungan sosial dengan kecemasan akademik siswa. Temuan ini sejalan dengan hipotesis yang diajukan, siswa yang memiliki religiusitas tinggi, kecerdasan emosional tinggi, dan dukungan sosial yang tinggi memiliki kecenderungan kecemasan yang rendah dalam dalam akademik.

Hasil penelitian menggambarkan bahwa profil religiusitas siswa yang sangat baik, hal ini bisa dilihat pada diagram berikut.

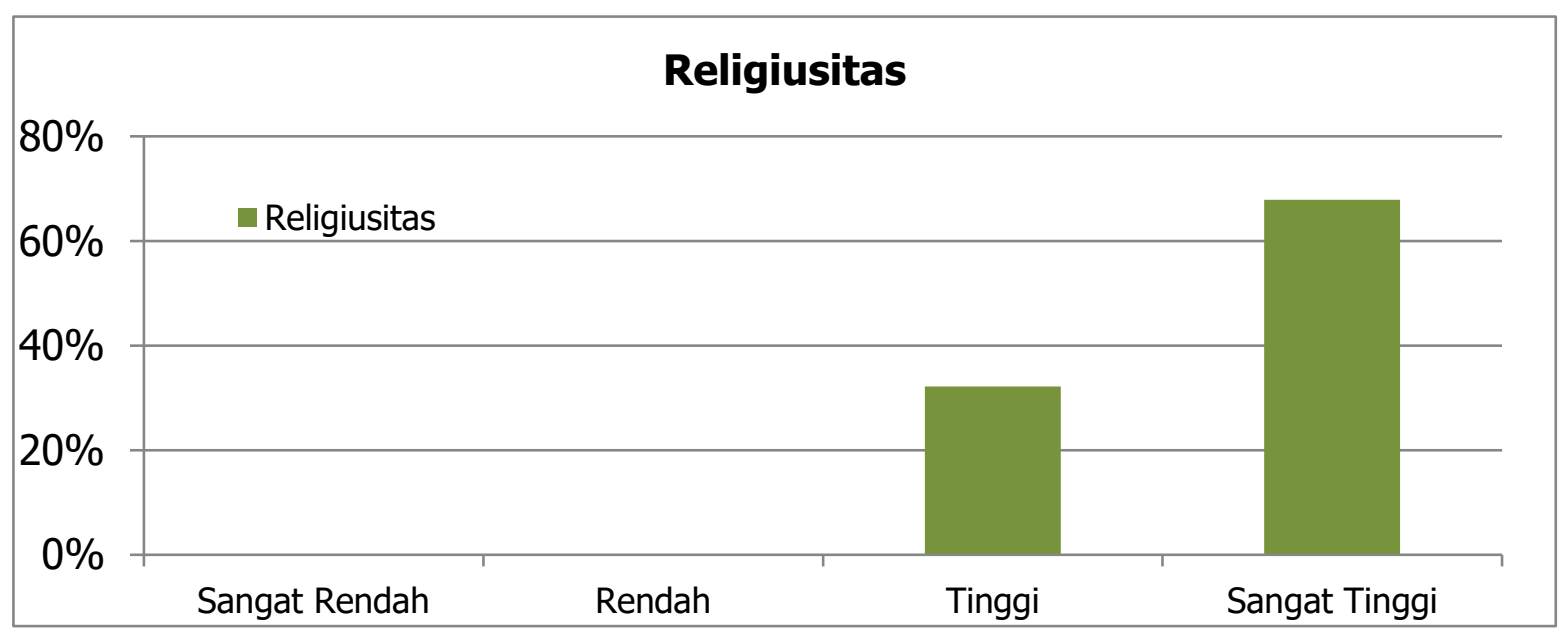

Gambar 1. Diagram Religiusitas Siswa 
Berdasarkan gambar diagram religiusitas siswa di atas, dapat di jelaskan bahwa sesuai dengan hasil penelitian tingkat religiusitas siswa dalam posisi sangat baik. Skor sangat tinggi dicapai oleh 57 siswa atau $67,86 \%$ dari total sampel dan 27 siswa atau $32,14 \%$ sampel mencapai skor tinggi. Religiusitas siswa dimanifestasikan dalam peribadatan ritual kepada Tuhan, berdoa, membaca kitab suci, mengikuti aktivitas sosial keagamaan lembaga agama dan perasaan berkemaknaan adanya Tuhan bagi kehidupan siswa. Hal ini sesuai dengan penelitian terdahulu bahwa tingkat pendidikan agama (religiusitas) siswa yang didukung dengan pola asuh yang demokratis mampu mengoptimalkan perkembangan konsep diri siswa sehingga dapat berperilaku positif (Mardliyah, 2021). Religiusitas mampu memberi jamian/kepastian dan kepercayaan diri, selain itu juga mampu meningkatkan perasaan aman dan mencegah timbulnya rasa cemas atau panik pada diri siswa. Siswa dengan tingkat religiusitas yang tinggi akan terhindar dari kecemasan akademik, sebaliknya siswa dengan tingkat religiusitas yang rendah mudah untuk mengalami kecemasan dalam melaksanakan tuntutan dan tugas akademik.

Profil kecerdasan emosional siswa juga menduduki tingkat yang sangat baik, yang terbukti dengan gambar diagram berikut.

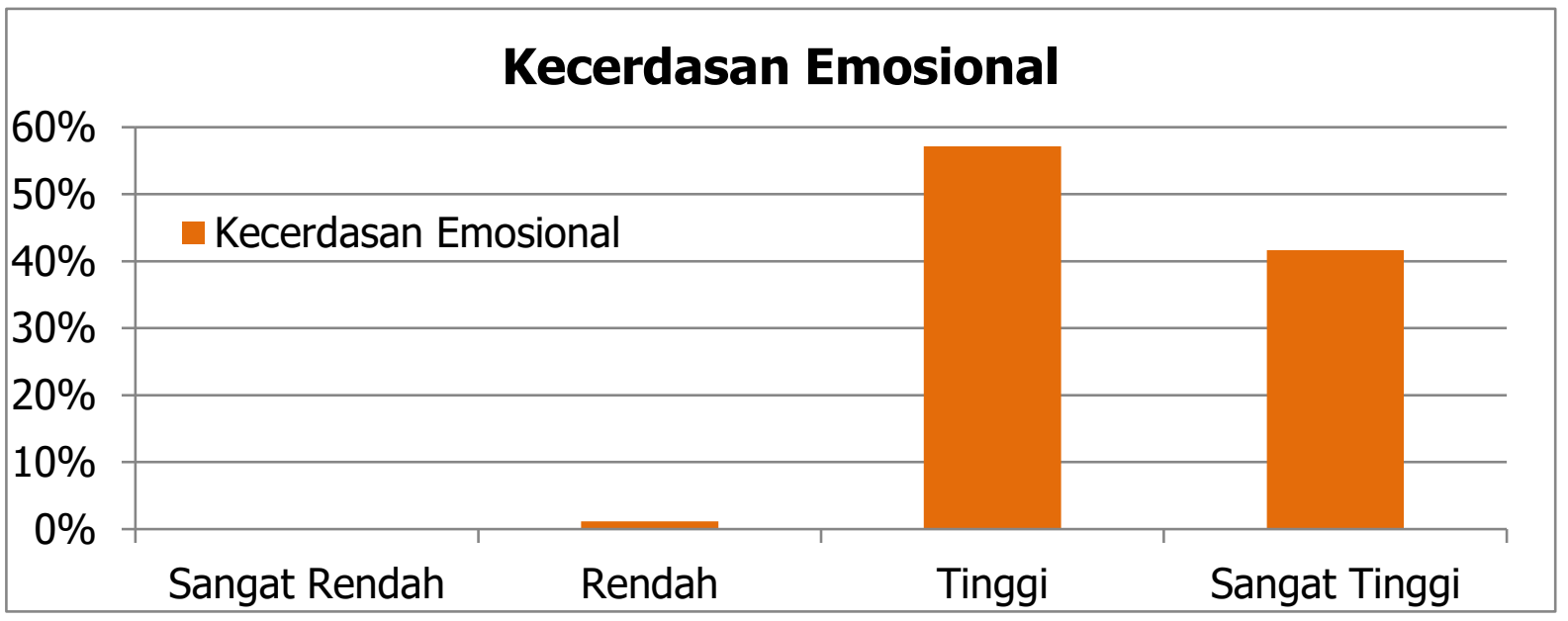

\section{Gambar 2. Diagram Kecerdasan Emosional Siswa}

Diagram di atas menunjukkan bahwa kecerdasan emosional siswa juga memperlihatkan hasil yang sangat baik, yakni 35 siswa (41,67\% sampel) mencapai skor sangat tinggi, 48 siswa $(57,14 \%$ sampel) memperoleh skor tinggi, dan 1 siswa (1,19\% sampel) memperolah skor rendah.

Kemampuan mengelola emosi sangat dibutuhkan ketika seseorang dihadapkan pada masalah yang berpotensi memunculkan perasaan tertekan atau kecemasan pada dirinya. Siswa yang mempunyai kecerdasan emosional yang lebih optimal mampu mengelola emosinya dengan lebih baik, sehingga mampu mengurangi dan menghindari rasa cemas dalam menghadapi tugas-tugas akademik. Tingkat kecerdasan emosional siswa yang semakin tinggi akan mereduksi kecemasan akademiknya. Siswa dengan kemampuan kecerdasan emosional yang baik akan 
mampu mengelola emosinya, sehingga membangun kekuatan yang lebih positif.

Intensitas relasi dengan orang lain yang intim dan positif akan menjadi pertahanan yang baik terhadap stres pada remaja, terutana hubungan dengan keluarga dan teman. Tingkat dukungan sosial yang memadai akan mampu mengontrol timbulnya tekanan dan kecemasan pada siswa. Siswa yang mendapatkan dukungan sosial yang cukup dan memperoleh pengalaman-pengalaman yang positif dalam kehidupannya, akan tumbuh rasa pernghargaan dalam dirinya dan menjadi pribadi yang optimistis.

Dukungan sosial memiliki kontribusi yang besar dalam kecemasan akademik siswa, diagram berikut menggambarkan profil dukungan siswa yang juga sangat baik.

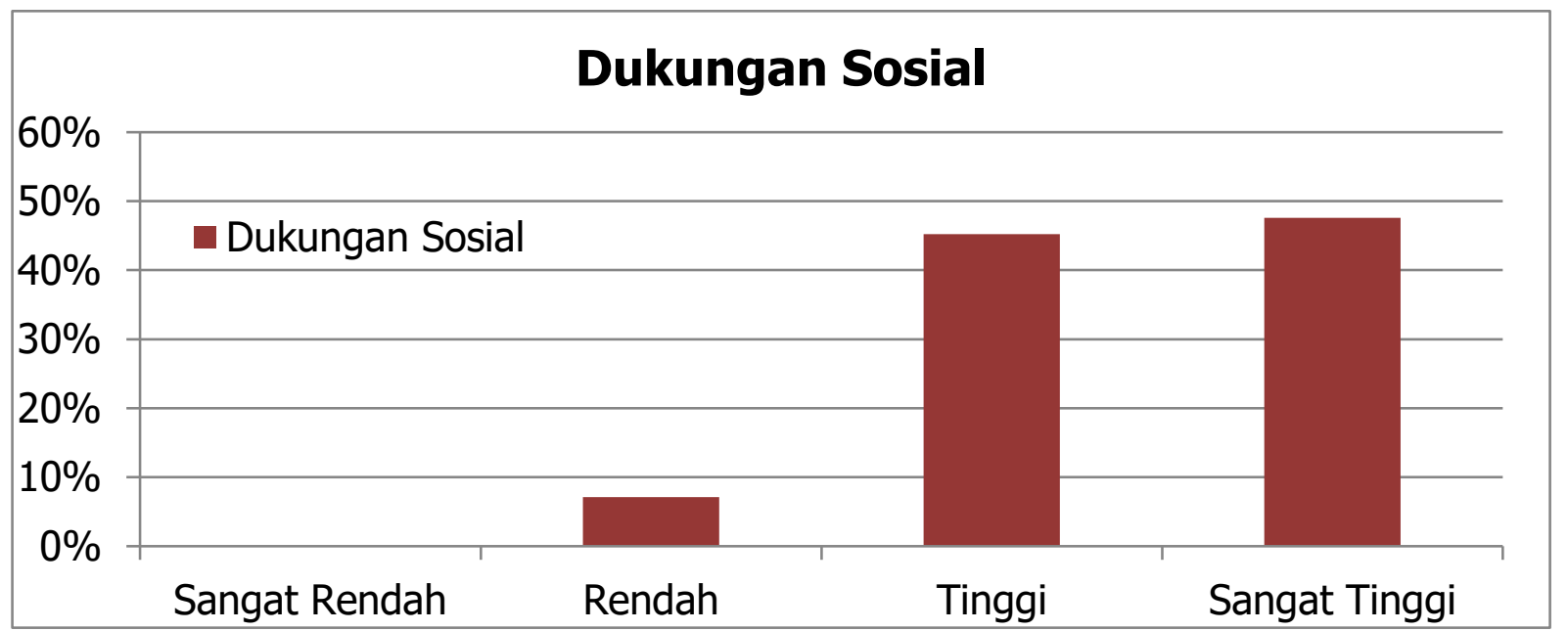

\section{Gambar 3. Diagram Dukungan Sosial Siswa}

Diagram di atas memperlihatkan bahwa tingkat dukungan sosial siswa mencapai skor sangat tinggi pada 40 siswa (47,62\% sampel), 38 siswa $(45,24 \%$ sampel) mencapai skor tinggi, dan enam siswa $(7,14 \%$ sampel $)$ dalam skor rendah.Dengan dukungan sosial yang cukup, siswa akan mampu menyadari adanya pihak lain di sekitarnya yang siap mendukung dan membantunya dalam menghadapi tekanan. Hal ini sesuai dengan penelitian terkait dukungan sosial orang tua terhadap prestasi siswa, yang menyatakan bahwa siswa yang mendapatkan dukungan sosial terlebih lagi dari dari orang tuanya, mereka cenderung mendapat prestasi belajar lebih baik daripada siswa yang minim perhatian dari orang tua (Sholekah dkk, 2019).

Kecemasan siswa merupakan variabel yang dipengaruhi oleh variabel religiusitas, kecerdasan emosional, dan dukungan sosial. Kecemasan siswa dalam penelitian ini sebanyak 8 siswa $(9,52 \%)$ mencapai skor sangat rendah, 57 siswa $(67,86 \%)$ mencapai sekor rendah, dan 19 siswa $(22,62 \%)$ mencapai skor tinggi. Gambaran tingkat kecemasan akademik siswa dapat dilihat pada diagram berikut. 


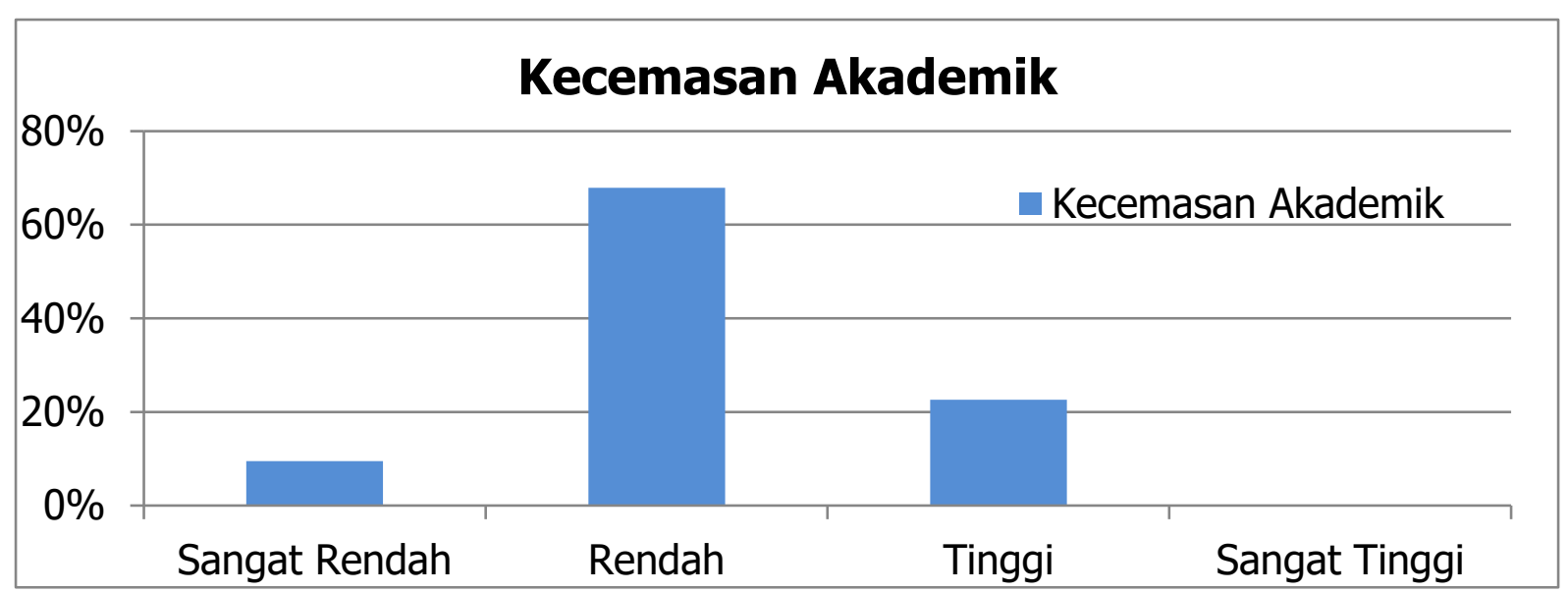

Gambar 4. Diagram Kecemasan Akademik Siswa

Hasil penelitian secara bersamaan variabel religiusitas, kecerdasan emosional, dan dukungan sosial mempunyai korelasi yang signifikan dengan kecemasan akademik siswa. Akan tetapi, jika dilihat secara parsial atau sendiri-sendiri maka didapatkan hanya variabel kecerdasan emosional yang secara signifikan mempunyai hubungan paling tinggi dengan kecemasan akademik. Sedangkan, religiusitas dan dukungan sosial secara signifikan memiliki hubungan yang hampir sama terhadap kecemasan akademik siswa.

\section{SIMPULAN}

Hasil penelitian menunjukkan keadaan religiusitas, kecerdasan emosional, dan dukungan sosial siswa rata-rata dalam kondisi sangat tinggi (sangat baik). Sedangkan kecemasan siswa dalam menghadapi ujian rata-rata mencapai skor rendah, yang berarti bahwa tingkat kecemasan siswa dalam kondisi baik.

Secara bersama-sama religiusitas, kecerdasan emosional dan dukungan sosial terbukti berkorelasi dengan kecemasan akademik siswa, namun jika dilakukan secara parsial, hanya dukungan sosial yang secara signifikan mempunyai hubungan dengan kecemasan siswa. Ketiga variabel memberikan sumbangan $10,7 \%$ terhadap kecemasan akademik siswa, Secara parsial kecemasan akademik dipengaruhi oleh religiusitas sebesar 3,2\%, kecerdasan emosional sebesar 4,4\%, dukungan sosial sebesar 3,1\%. Sedangkan masih banyak faktor-faktor selain variabel yang diteliti yang memberikan pengaruh sebesar 89,3\% terhadap kecemasan akademik siswa.

Siswa diharapkan mampu meningkatkan religiusitas dalam kehidupan sehari-hari dan mengetahui serta mengarahkan segenap kekurangan dan kelebihan dalam dirinya. Sekaligus mampu menjalin hubungan sosial yang baik dengan lingkungan di sekitarnya.

Keluarga merupakan pendidikan yang pertama dan utama bagi anak. Orang tua diharapkan mampu meningkatkan pendidikan religi dan dukungan bagi anaknnya, karena dukungan dari orang tua adalah lebih bermakna dan berharga daripada dukungan dari luar.

Menindak lanjuti hasil temuan ini disarankan lembaga pendidikan (sekolah) untuk meningkatkan kecerdasan emosi, dan 
menyelenggarakan acara-acara yang memiliki nilai-nilai religius. Serta diharapkan mampu memberikan dukungan kepada siswa baik berupa dukungan emosional, penghargaan, instrumental/materi, maupun yang bersifat informatif.

\section{DAFTAR PUSTAKA}

Asnani, L. S. (2004). Hubungan antara Kecerdasan Emosional dengan Kecemasan Bertanding pada Olahragawan Bola Voli Surabaya Flame. IAIN Sunan Ampel.

Cohen, S., \& Wills, T. A. (1995). Stress, Social Support, and the Buffering Hypothesis. Psychological Bulletin, 98(2), 310-357.

Farid, M. (2011). Hubungan Penalaran Moral, Kecerdasan Emosi, Religiusitas, dan Pola Asuh Orangtua Otoritatif dengan Perilaku Prososial Remaja. Disertasi: Universitas Gajah Mada.

Goleman, D. (2002). Emitional Intelligence (Terjemahan). Jakarta: PT. Gramedia Pustaka Utama.

Hawari, D. (1997). Al-Qur'an IImu Kedokteran Jiwa dan Kesehatan Jiwa. Dana Bhakti Prima Yasa.

Ifdil, \& Bariyyah, K. (2015). The Effectiveness of Peer-Helping to Reduce Academic-Stress of Students. Addictive Disorders and Their Treatment, 14(4).

Koenig, H. G., George, L. K., \& Titus, P. (2004). Religion, Spirituality, and Health in Medically Ill Hospitalized Older Patients. Journal of the American Geriatrics Society, 52(4).

Madoni, E., Wibowo, M., \& Japar, M. (2018). Group Counselling with Systematic
Desensitization and Emotional Freedom Techniques to Reduce Public Speaking Anxiety. Jurnal Bimbingan Konseling, $\pi(1), 28-35$

Mardliyah, A. (2021). Determinasi Pendidikan Agama Islam Dan Pola Asuh Demokratis Terhadap Akhlak Remaja. MUROBBI: Jurnal IImu Pendidikan, 5(1), 1-16.

Mayer, J. D., Salovey, P., \& Caruso, D. R. (2004). Emotional Intelligence: Theory, Findings, and Implications. In Psychological Inquiry (Vol. 15, Issue 3$)$.

Nevid, J. S., Rathus, S. A., \& Beverly, G. (2005). Peikologi Abnormal Edisi Kelima Jilid I. Terjemahan: Tim Fakultas Psikologi Universitas Indonesia. Erlangga.

Nuraini, D. E. (2013). Kecerdasan Emosi dan Kecemasan Menghadapi Pensiun pada PNS. Psikoborneo: Jurnal IImiah Psikologi, 1(3), 192-196.

O'Connor, F. (2008). Frequently Asked Questions About Academic Anxiety. The Rosen Publishing Group.

Papalia, D. E., Olds, S. W., \& Feldman, R. D. (2007). Human development, 10th ed. In Human development, 10th ed. McGraw-Hill.

Puteh, M., \& Z., K. (2016). Mathematics Anxiety and Its Relationship with the Achievement of Secondary Students in Malaysia. International Journal of Social Science and Humanity, 6, 119122.

Schunk, D., Meece, J., \& Pintrich, P. (2014). Motivation in Education Theory, Research, and Applications. Pearson/Merrill Prentice Hall. 
Sholekah, S., Swastinah, T., \& Masjkur. (2019). Perhatian Orang Tua Terhadap Prestasi Belajar Siswa Kelas V SD Negeri Ampel 04 WuluhanJember. Jurnal Consulenza:Jurnal Bimbingan Konseling Dan Psikologi, 2(2), 62-67.

Sugiono. (2014). Metode Penelitian Pendidikan (Pendekatan Kuantitatif, Kualitatif dan R\&D). Bandung: Alfabeta.
Ukhtia, F., Reza, I. F., \& Zaharuddin. (2016). Hubungan antara Religiusitas dengan Kecemasan Akademik pada Siswa Madrasah Aliyah Negeri. Psikis: Jurnal Psikologi Islami, 2(2), 146-160.

Wahid, S. N. S., Yusof, Y., \& Nor, A. H. M. (2018). Effect of mathematics anxiety on students' performance in higher education level: A comparative study on gender. AIP Conference Proceedings,

1974. 